The obliquity of these suborbicular valves (about $60^{\circ}$ ) approximates to that of Cyclestheria, as defined by G. O. Sars ${ }^{1}$; but the latter is much more nearly circular in outline (Fig. 6).

The more protuberant umbo, further from the anterior corner, and the more distinctly level straightness of the hinge-line behind it, are distinctive characteristics, as well as the somewhat more prolate antero-dorsal region of the valve in front of the umbo.

(To be concluded in our next Number.)

\title{
ITOTICES OF MTEMOIRS.
}

\section{I.-On the Distribution of Marine Mammals. ${ }^{2}$ By P. L. Sclater,} M.A., Ph.D., F.R.S., Sec. Zool. Soc.

(Read before the Zoological Society, March 16, 1897.

I. Introductory Remarks.-Most of the recent writers on Geographical Distribution have confined their attention to terrestrial mammals, or at any rate have but casually alluded to the marine groups of that class. On the present occasion I wish to call your attention to some of the principal facts connected with the distribution over the world's surface of the marine or aquatio members of the Class of Mammals.

Aquatic mammals, which pass their lives entirely, or, for the greater part, in the water, are, of course, subject to very different laws of distribution from those of the terrestrial forms. As regards aquatic mammals, land is of course an impassable barrier to their extension, and, subject to restrictions in certain cases, water offers them a free passage. Just the opposite is the case with the terrestrial mammals, to which in most cases land offers a free passage, while seas and rivers restrain the extension of their ranges.

The groups of aquatic mammals that are represented on the earth's surface at the present time are three in number, viz.: (1) the suborder of the Carnivora, containing the Seals and their allies, generally called the Pinnipedia, which are semi-aquatic; (2) the Sirenia, which are mainly aquatic; and (3) the Cetacea, which never leave the water, and are wholly aquatic. We will consider briefly the principal representatives of these three groups, following nearly the arrangement of them employed in Flower and Lydekker's "Mammals, living and extinct."

1 Christiania Vidensk.-Selsk. Forhandl, 1887, No. 1, pl. i, figs. 1-3. Dr. Baird gave a rather more symmetrical form to this subcircular species (Proc. Zool. Soc. 1859 , p. 232 ; and 1860 , p. 188 , pl. lxiii, fig. 1), triangular on the dorsal and rounded on the ventral margin. His figure, if placed with the hinge-line horizontal, shows a subcentral umbo, with the hinge-line almost level behind it, and equal to half of the transverse diameter of the valve. There is a rapid slope in front, meeting the anterior part of the more than semicircular free margin.

2 For the Land-Provinces proposed by the author for the Geographical Distribution of Birds, see Dr. P. L. Sclater's paper in Journ. Proc. Linn. Soc. (Zoology) 1858, vol. ii, pp. 130-45; also Rep. Brit. Assoc. 1860, Trans. Sec., pp. 121, 122 ; H. Woodward, Geol. MaG. 1885, Decade III, Vol. II, p. 315, and Proc. Geol. Assoc. 1886, vol. ix, No. 5, p. 366. 
II. Distribution of Pinnipeds.-The Pinnipeds, which I will take first, comprise three distinct families-- the Otariidx, the Trichechidæ, and the Phocidæe. Beginning with the Otariidæ or Eared Seals, commonly known as Sea-lions and Sea-bears, we find the greater number of the species confined to the South Polar Ocean, where they pass most of their time at sea, but, as is well known, resort to the land at certain seasons for breeding purposes. In the Atlantic Ocean, so far as 1 know, the Eared Seals have never been ascertained to occur further north than the estuary of the La Plata on the American coast, and the vicinity of the Cape on the African coast. But in the Pacific, on the contrary, three distinct species of Otaria are found all over the Arctic portion of that ocean, and there are well-founded traditions of Eared Seals having been formerly met with in the Galapagos, while they still occur on the coast of Peru and Chili. I think, therefore, we may assume that Otaria was originally an Antaretic form, but has travelled northwards along the West American coast and is now firmly established in the North Pacific. In a parallel way in the class of birds, the Albatrosses (Diomedea), which are essentially a group of the Antarctic seas, are represented by three distinct species in the North Pacific.

The second family of the marine Carnivora, on the other hand, the Walruses (Trichechidæ), are entirely Arctic in their distribution; one species (Trichechus rosmarus) being peculiar to the North Atlantic, while a second nearly allied species ( $T$. obesus) takes its place in the Northern Pacific.

The third family of Pinnipeds is more numerous and varied, both in genera and species, than the two preceding, and has a more extended range. The Seals (Phocidæ), embracing about nine different generic forms, are most numerous in the Arctic and Antarctic seas, but are also feebly represented in some intermediate localities. Beginning with the North Atlantic, we find several species of Phoca inhabiting various parts of this area, and the Grey Seal (Halichorus) and the Bladder-Seal (Cystophora) exclusively confined to it. In the North Pacific all the four true Seals belong to the genus Phoca, and three of them are identical with the North Atlantic species, but when we descend as far south as the Gulf of California on the American coast we meet with a species of Sea-elephant (Macrorhinus) which, like Otaria, has no doubt penetrated up here thus far from its ancestral abode in the Antarctic Ocean.

Returning to the Central Atlantic, we find two species of Seals inhabiting these waters, both belonging to the same genus Monachns. One of these (M. albiventer) inhabits the Mediterranean and the adjoining coasts of the Atlantic, while the other (M. tropicalis) is in these days restricted to some of the smaller and less known islands of the West Indies.

The Phocidæ of the Antarctic Ocean all belong to genera distinct from the Arctic forms and more nearly allied to Monachus, the Seal of the Mid-Atlantic. They are of four species belonging to as many genera: Ogmorhinus, Lobodon, Leptonychotes, and Ommatophoca. Besides these the Sea-elephant of the whalers (Macrorhirus) is 
essentially an Antarctic form, though now nearly extinct there, after long persecution by man. But, as already noted, it extends, or has in former days extended, far up the West coast of America, and is still occasionally found on Santa Barbara Island on the coast of California.

III. Distribution of Sirenians.-Only two forms of Sirenians are at the present time existing on the earth's surface-the Manatee (Manatus) and Dugong (Halicore)--each representing a distinct family of the order. The Manatee is an inhabitant of the coasts and estuaries of both sides of the middle Atlantic Ocean - one species (Manatus Senegalensis) occurring on the African shores, and another (M. Americanus) on the Sonth American coast and in the Antilles. A third species (M. inunguis), so far as we know at present, is found only in fresh water bigh up the Amazons.

The Dugong (Halicore) is distributed from East Africa, along the shores of the Indian Ocean and its islands, to North Australia. Three species of this genus have been established - Halicore tabernaculi from the Red Sea, $H$. dugong from the Indian Ocean, and $H$. Australis from Australia; but it is doubtful how far these forms are actually distinguishable.

Beside Manatus and Halicore, a third quite distinot form of Sirenian was formerly an inhabitant of the North Pacific. 'This was Steller's Sea-cow (Rhytina Stelleri), by far the largest animal of the group, which was exterminated by human agency about 1768 . Fortunately recent researches in Behring's Island have been successful in supplying specimens of its skeleton for our principal Museums, and Steller, its discoverer, left to posterity a good account of its habits and anatomy.

IV. Distribution of Cetaceans.-Adopting the recognized division of the Cetaceans into two suborders, Mystacoceti and Odontoceti, according as to whether their mouths are furnished with baleen ("whalebone") or teeth, we will first consider the True or Whalebone Whales, which consist of a single family, Balænidæ, usually divided into five genera: Balcena, Neabalana, Rhachianecles, Megaptera, and Balanoptera. Of these, Balcena, Megaptera, and Balonoptera are almost cosmopolitan-species of them, whether distinct or not is at present more or less uncertain, being met with in nearly every part of the ocean. But Rhachianectes has as yet been ascertained to occur only in the Northern Pacific, and Neobalana in the South Polar Ocean, so that we have in these cases two well-marked local types to deal with.

The Toothed Wales (Odontoceti) are more diversified than the preceding group, and are usually held to embrace at least four existing families besides several extinct forms. The first family, containing the Physeteridæ or Sperm-Whales, consists of at least six genera (Physeter, Cogia, Hyperoodon, Ziphius, Mesoplodon, and Berardius). Physeter and Cogia are inhabitants of the whole oceanic area between the tropies, extending in certain localities some way beyond them. Hyperoodon is confined to the North Atlantic. Ziplius has an extensive range, and has been found in uearly every 
part of the ocean. Mesoplodon is also widely distributed, but is apparently more abundant in the Southern Hemisphere. Berardius, however, so far as we know at present, is restricted to the South Polar Ocean.

The third family of Toothed Whales contains only the Platanistidæ, or Fresh-water Dolphins, which, although, in some cases, at the present day entirely fluviatile, must probably have descended from oceanic forms. The three known genera are Platanista of the Ganges and Indus, Inia of the river Amazons, and Pontoporia of the river La Plata; the last form making a connecting link between the two preceding genera and the marine Dolphins.

The fourth family of Toothed Whales, containing the Dolphins, Delphinidæ, is very numerous in species and embraces at least fifteen or sixteen genera. But in spite of the effurts of Mr. True, who has recently given us an excellent summary of our present knowledge of them, ${ }^{1}$ both the genera and species of Delphinidæ are still so imperfectly understood that I cannot say much about their geographical distribution. Most of the forms appear to be very widely distributed, but it may be said generally that Dolphins are most abundant in the intertropical seas and less plentiful both to the north and south of them.

There are, however, two forms that are exclusively inhabitants of the North Atlantic. These are the very remarkable Narwhal (Monodon), in which the male is furnished with a single enormous horn-like tusk, and the Beluga or White-Whale (Delphinapterus), closely allied to the Narwhal in many points of its general structure. These may be looked upon as quite isolated forms characteristic of the Arctic portion of the Atlantic, but not known in the Pacific.

V. Division of the Marine Area of the Globe into Sea-regions.From wbat has been already said, it will be evident that, although many of the marine mammals have a wide distribution, others are very definitely localized; and a study of the latter will, I think, enable us to divide the oceanic portion of the globe into six Searegions, corresponding to a certain extent with the six Land-regions ${ }^{2}$ into which I proposed to separate the terrestrial portion of the globe in 1874 , and which were subsequently adopted by Mr. Wallace in his standard work on the Geographical Distribution of Animals. I propose to call these Sea-regions-

(1) The North Atlantic Sea-region or Arctatlantis (äpкros and 'A ${ }^{\prime} \lambda a \nu \tau i$ 's = the daughter of Atlas), consisting of the northern portion of the Atlantic down to about $40^{\circ} \mathrm{N}$. lat.

(2) The Mid-Atlantic Sea-region or Mesatlantis (ú́ros and 'Ar $\lambda a \nu \tau i$ 's), consisting of the middle portion of the Atlantic down to about the Tropic of Capricorn.

"See "A Review of the family Delphinidæ," by Frederick W. True: Bull. U.S. Nat. Mus., No. 36, Washington, U.S., 1889.

${ }_{2}$ Presidential Address, Sect. Biology, Brit. Assoc. 1875 (Bristol); and Proc. Roy. Inst., vol. viii, pp. 511-13 (1878). 


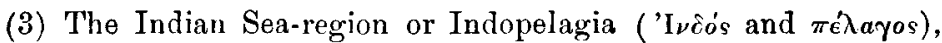
containing the Indian Ocean down to about the same degree of S. lat., and extending from the coast of Africa on the west to Australia and the great Oriental islands on the east.

(4) The North Pacific Sea-region or Arctirenia (ü $\rho \kappa \tau o s$ and eipíp $=p a x)$, containing the northern portion of the Pacific Ocean down to about the Tropic of Cancer.

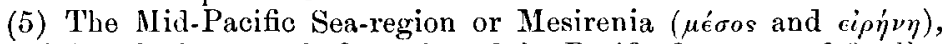
containing the intertropical portion of the Pacific Ocean ; and finally,

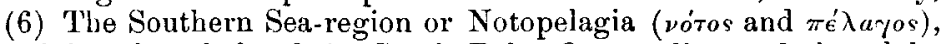
containing the whole of the South Polar Ocean all round the globe south of the above-mentioned limits.

We will now proceed to consider shortly the characteristic Mammals of these six Sea-regions.

VI. The North Atlantic Sea-region, or Arctatlantis.-Amongst the Pinnipeds two well-marked generic forms, the Grey Seal (Halichorus) and the Bladder-Seal (Cystophora), are exclusively confined to Arctatlantis. The True Seals (Phoca) and the Walrus (Trichechus) are found in this region and in Arctirenia; and of the former genus three species ( $P$. vitulina, $P$. Gronlandica, and $P$. barbata) are actually common to both these Sea-regions, while the Walruses (Trichechus rosmarus and T. obesus) of the two Sea-regions are perhaps somewhat doubtfully distinguishable. It may be easily understood how this has come to pass, because the Seals and Walrus may in the course of time, during unusually mild summers, have extended themselves along the north coast of the American continent into the Northern Pacific. But Arctirenia, as we shall presently show, is markedly distinguishable from Arctatlantis by the presence of Eared Seals (Otaria), which are utterly unknown in the whole of the Atlantic area. Otaria is, in fact, as regards Arctatlantis what I have called on previous occasions (see P.Z.S. 1882, p. 311) a "lipotype" of Arctatlantis, but what I now propose to designate a "lipomorph." 1

The Sirenians are entirely absent from the North Atlantic and constitute another lipomorph of that area.

Coming to the Whales, we find the Mystacoceti well represented in the North Atlantic by Balena, Megaptera, and Balcenoptera, but of these the two latter are almost universally distributed over the ocean, and Balena recurs again in the North Pacific as well as in more southern latitudes, so that there is no genus of Whalebone Whales peculiar to Arctatlantis, although the great Balana mysticetus has never been found elsewhere.

Proceeding to the Odontoceti, the case is different. Amongst the

1 On former occasions I have used the term "lipotype" for a natural group which characterizes a particular locality by its absence. It would, however, perhaps be better to change the term to "lipomorph," because the type and its compounds have been generally employed in reference to the particular specimens of a species upon which original descriptions are based (cf. 'Thomas, P.Z.S. 1893, p. 241). In the same way a natural group which characterizes a particular country

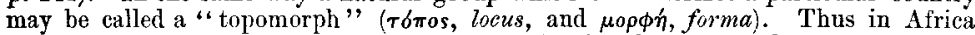
Giraffa and Phacocharms would be "topomorphs," and Cervus and Uisus would be "lipomorphs." 
Physeteridæ, Hyperoodon is confined to Arctatlantis, and, as already explained, two very well-marked types of the Delphinidæ, Delphinapterus and Monodon, are likewise exclusively denizens of the North Atlantic ocean. Arctatlantis, therefore, may be said to be well characterized by the possession of at least five genera of Marine Mammals not found elsewhere, viz. Halichorus, Cystophora, Hyperoodon, Delphinapterus, and Monodon.

VII. The Middle Atlantic Sea-region, or Mesatlantis.-Mesatlantis has certainly not so many forms of Marine Mammals confined to its area as Arctatlantis, but there seem to be good grounds for its separation. As we descend towards the tropics the true Seals (Phocinæ), which are constituted to live in colder water, gradually fall off in number, and in Mesatlantis are no longer met with. But in their place we find the genus Monachus or Monk-Seal restricted to Mesatlantis, one species (M. albiventer) occurring in the Mediterranean and on the North African coast, and a second (M. tropicalis) being found in the West Indies. Mesatlantis is likewise the true home of the well-marked Sirenian genus Manatus, one species of which (M. Americanus) frequents the coast of America and another (M. Senegalensis) that of Africa.

As regards the Cetaceans we are not able to say that Mesatlantis, although well furnished with many generic types of this Order, has anyone peculiar to it. We must therefore rest content with assigning two genera of Marine Mammals, Monachus and Manatus, as characteristic forms or topomorphs of the Sea-Mammal life of Mesatlantis.

VIII. The Indian Searregion, or Indopelagia. - The Marine Carnivora, so far as we know, are entirely foreign to Indopelagia, but the Sirenians are well represented by the Dugong (Halicore), which pervades all its northern coasts from North Australia to India and the Red Sea and down the African coast to Lamu. ${ }^{1}$ Whether the species of Halicore found at different points within this area are the same or different, is still a matter of discussion, but there can be no doubt that Halicore is an exclusive inhabitant of Indopelagia. As regards the Whales of Indopelagia, we know that Physeter, Cogia, and Ziphius, and numerous forms of Delphinidæ occur there. but I am not aware of any Cetacean that is entirely restricted to this Sea-region.

IX. The North Pacific Sea-region, or Arctirenia.-As was pointed out when speaking of Arctatlantis, Arctirenia has one genus of Phocidæ (Phoca) in common with the North Atlantic, and three of the species of this genus appear to be actually identical in these two Sea-regions, whilst a fourth Phoca ( $P$. fasciata) is only found in the North Pacific. The Walrus (Trichechus) is again a form of Marine Mammals common to both the great northern Sea-regions. But the feature of Pinnipedian life that absolutely distinguishes Arctirenia from Arctatlantis is the presence in the former of three (if not four) well-marked species of the Eared Seals (Otariidæ), which are absolutely unknown in the vast extent of the Atlantic down at least to $30^{\circ} \mathrm{S}$. lat.

1 A fine specimen of the Dugong from Iamu (on the east coast of Africa, lat. $2^{\circ} 50^{\prime}$ S.), obtained by Mr. J. C. Haggard in 1885, is in the British Museum. 
Arctirenia has unfortunately lost its Sirenian, Steller's Sea-cow (Rhytina Stelleri), the largest and finest modern representative of this formerly prevalent group, which since the days of the Pleistocene has greatly diminished in numbers, but $I$ think we may still treat Rhytina as one of the characteristic forms of the Arctirenian Searegion. The North Pacific is also even at the present day the sole possessor of a remarkable genus of Whalebone Whales which combines the long head and elongate form of Balanoptera with the smooth skin of the throat and absence of the dorsal fin of Balana. ${ }^{1}$ This is the Grey Whale, Rhachianectes glaucus of Cope, which, in these days, is confined to the North Pacific, and does not range farther south that the 20 th parallel in that ocean. At the same time it should be stated that indications have been discovered that a nearly allied form existed in the Atlantic in previous geological ayes, though this is by no means certain. Besides Rhachianectes, Balena, Megaptera, and Balonoptera are all represented in the North Pacific, and also many species of Delphinide, of which little is at present known. But Rhytina and Rhachianectes are the only genera of Marine Mammals absolutely confined to Arctirenia.

X. The Middle Pacific Sea-region, or Mesirenia.-The Eared Seals, Otaria, must have necessarily passed through Mesirenia in their passage from south to north, though the only record of their recent presence in the central part of the Pacific is, so far as I know, the report that they were formerly found in the Galapagos. It should be stated, however, that Tschudi records the occurrence of two species of Otaria on the islands of the coast of Peru, and that in 1802 Humboldt met with an Eared Seal on the Island of San Lorenzo, in the Bay of Callao, which is only some $12^{\circ}$ south of the Equator.

Like Otaria, the Sea-elephant (Macrorhinus) has apparently in former ages travelled up the South American shores and established itself as far north on the coast of California at about $34^{\circ} \mathrm{N}$. lat. The Californian Sea-elephant has been discriminated by Gill as a distinct species (Macrorhinus angustirostris), but its differences from the southern form (M. leoninus) seem to be but trifling.

As regards the Cetaceans of Mesirenia, our information is at present very imperfect, and I have little to say except that species of Megaptera, Balcenoptera, Physeter, Cogia, and Ziphius certainly occur there, besides many representatives of the widely-spread Delphinidæe.

XI. The Southern Polar Sea-region, or Notopelagia.-The wide ocean which surrounds the Southern Pole on every side, and extends up to $40^{\circ} \mathrm{S}$. lat., seems to present, as regards its marine mammals, a nearly homogeneous fauna, which we will now briefly consider. In the first place it contains representatives of four genera of true Phocidæ-Ogmorhinus, Lobodon, Leptonychotes, ${ }^{2}$ and Ommatophoca,

1 Flower and Lydekker, "Mammals," p. 241.

2 This generic term, established by Gill in 1872 , seems to take precedence of Pacilophoca, proposed by Flower and Lydekker for the same type (L. Weddelli) in 1891. Cf. Allen, "North American Pinnipeds," p. 418. 
which are peculiar to the southern seas, and are quite distinct from all their northern representatives in the Arctic Ocean. The Seaelephant, Macrorhinus, is also a denizen of Notopelagia, though, as we have already seen, it has wandered north along the South American coast far into Mesirenia.

Like Macrorhinus, Oturia also, containing the group of Eared Seals, appears to have been originally an Antarctic group, and the greater number of its species, although nowadays very much reduced in numbers, are still found in the Southern Ocean. But the Otaria have travelled still further north than Mrtcrorhinus, and three, if not four, species, as already stated, are in these days wellestablished inhabitants of Arctirenia.

The Sirenians are absent from Notopelagia, but Cetaceans of every kind are abundant. Besides one or more representatives of the true Whalebone Whale (Balana), Notopelagia has a smaller representative of the group (Neobalana) entirely restricted to its areat. It has also representatives of Megaptera and Balcenoptera, though it is doubtful how far they are even specifically distinct from some of their northern representatives.

Among the Toothed Whales (Odontoceti) we find a large Ziphioid form, Rerardius, restricted to the Notopelagian area, while Ziphius and Mesoplodon also occur there. The Dolphins (Delphinidæ) are likewise numerous, and present some distinct species, but not, so far as our present knowledge extends, any generic forms that do not occur elsewhere.

But Notopelagia is sufficiently distinguished from all the five more northern sea-regions by possessing four genera of Seals and two of Cetaceans entirely restricted to its area.

XII. Conclusions. - It has therefore, I think, been shown that for the Geography of Marine Mammals, the Ocean may be most conveniently divided into six Sea-regions, as follows :-

I. Regio Arctatlantica, characterized by its Seals (Phocinæ), of which two genera, Halichorus and Cystophora, are peculiar, whilst Phoca is common to it and Arctirenia; by the absence of Sirenians; and by the possession of three peculiar genera of Cetaceans (Byperoodon, Delphinapterus, and Monodon).

1I. Regio Mesatlantica, sole possessor of the Monk-seal, Monachus, amongst the Pinnipeds, and of the Sirenian genus Manatus.

III. Regio Indopelagica, characterized by the presence of the Sirenian Halicore and by the absence of Pinnipeds.

IV. Regio Arctirenica, with Phoca like the Regio Arctatlantica, but having Otaria also; the home of the (now extinct) Sirenian Rhytina and of the endemic Cetacean Rhachianectes.

V. Regio Mesirenica, without true Seals (Phocina), but having Otaria and Macrorhinus from the South; no Sirenian known.

VI. Regio Notopelagica, charecterized by four endemic genera of Phocidæ, and by the presence of many Otaria; without Sirenians, but with two endemic forms of Cetaceans (Neobalana and Berardius).

In conclusion, I will call attention to sume of the more remarkable 
points in the general distribution of the marine Mammals, and to their apparent significance.

In the first place, it is evident that the Pacific has much more in common with the Notopelagian region than the Atlantic. Otaria and Macrorhinus, quite unknown in the Atlantic, extend themselves to the northern extremity of the Pacific, the former pervading that ocean up to Behring's Straits, and the latter reaching to the Californian coast. It follows that in former ages there must have been some barrier in the Atlantic which did not exist in the Pacific to stop their progress northwards. The only barrier I can imagine that would have effected this must have been a land uniting South America and Africa, across which they could not travel. Adopting this hypothesis, we have at the same time an explanation of the presence of the Manatee on both the American and African coasts. The Manatee could hardly live to cross the Atlantic. It is only found close to the coast, where it browses on seaweeds and other vegetable food in shallow water. How did it travel from America to Africa (or vice versa), unless there were a continuous shore-line between them? The same may be said of the Monk-seal (Monachus), of which one species lives in the Mediterranean and on the African coast and islands, and another in the West Indies. We can hardly believe that these creatures could easily traverse the whole Atlantic.

Topomorphs of the Sha-regions.

I. Arctatlantis.

Halichorus.

Cystophora.

Hyperoodon.

Delphinapterus.

Monodon.

II. Mesatlantis.

Monachus.

Manatus.

Inia.

Pontoporia.
IV. Ardtirenia.

Otaria.

Rhytina (extinct).

Rhachianectes.

III. Indopelagia.

Halicore.

Plantanista.

V. Musirenia.

Otaria.

Macrorhinus.

\section{Notopelagia.}

Ogmorhinus.

Lobodon.

Leptonychotes. Ommatophoca.

Otaria.

Neobalana.

Berardius.

DRCADE IV.-TOL. IV.-NO. VI. 
The hypothesis of a former barrier of land between Africa and America, which we know is supported by other facts of distribution, ${ }^{1}$ would alone explain the difficulty.

On the other hand, in the Pacific we find no such break between the north and south. The aquatic Mammals of Notopelagia have evidently had free access to the whole of the Pacific for a long period, and have well availed themselves of this facility.

Again, while the great Southern Ocean exhibits a considerable uniformity of marine mammalian life, we see the Northern waters divided into two distinctly recognizable regions by the interposed masses of land. All these facts, with the one exception of the supposed Atlantic barrier, would tend in favour of the now generally accepted doctrine that the principal masses of land and water are not of modern origin, but have existed mainly in their present shapes throughout all ages.

\section{II.-Reconhecimento Geologico dos Territorios Portuguezes,} comprehendidos entre Lourenco Marques e o Rio Zambeze. Por Alfredo A. Freire de Andrade. Dissertação para o concurso da $7^{\text {a }}$ Cadeira da Escola Polytechnica. (Lisboa: Imprensa Nacional, 1894.)

A Geological Reconnaissance of the Portuguese Territories between Lorenzo Marques and the Zambesi River. By A. A. Freire de Andrade. Competitive dissertation for the seventh Chair in the Polytechnic School. 8ro; pp. 184, with a geological sketch-map. (Lisbon, 1894.)

THIS memoir contains an instructive description of the main geographical and geological features of that part of the Portuguese Province of Mozambique which lies south of the Zambesi River. Apart from its natural features, the region is of considerable interest at the present time, from its position between the 'Transvaal and the British South African Company's Territories on the one hand, and the sea on the other. In most English maps the country is divided into the districts of Gaza, Sofala, Manica, Sena, and Tete, but only three divisions are given in this paper, namely, the districts of Lorenzo Marques and of Inhambane on the south, and the Territories of the Mozambique and Zambesi Companies on the north. The Lorenzo Marques district consists almost exclusively of low, flat, or slightly undulating areas, bounded on the west by the porphyritic mountains of the Limbombos range, which run northwards from the Natal boundary. The range is traversed by numerous rivers, the most important being the Incomati, the Elephant, and the Limpopo. The Inhambane district is likewise a nearly flat, sandy plain of an average elevation of 300 mètres, which extends between the Limpopo and the Save River. Near the coast, the level of the country abruptly falls towards the sea. Many of the rivers and the lagoons of this district are Iargely charged with saline materials.

1 Cf. Wallace, “Geogr. Distrib.," vol. i, p. 156. 
North of the Save River, in the Mozambique and Zambesi Companies' territories, the aspect of the country entirely changes; instead of sandy plains there is a succession of undulations of gradually increasing elevation, which beyond the Morungueze reach to the summit of the plateau, at levels of 1000 to $1200 \mathrm{~m}$. Beyond the Lusiti River, running from south to north, is the walllike range of the Chimanimani Mountains, the summits of which are $2000 \mathrm{~m}$. above the sea. The principal rivers of this northern district are the Zambesi, Pungue, Revue, Lusiti, Busi, Mossurize, and the Save. A large portion of this area consists of gneiss and granite, which extend to near the coast and then disappear beneath modern alluvium. The author distinguishes (1) granitoid gneiss passing into granite, (2) gneiss with intercalated beds of pyroxene and with garnets and amphibolites, and (3) mica schists and chloritic schists.

In the country between Lorenzo Marques and the Zambesi there is a close connection between the altitude and the geological structure, so that it is possible to divide it into three principal zones. The lowest or coast zone, reaching from sea-level to $300 \mathrm{~m}$., consists for the most part of Tertiary sediments, modern alluvial deposits, and sand-dunes. A large part of the southern districts of Lorenzo Marques (except the Limbombos Mountains) and Inhambane, and a small part of the Companies' territories, are included in this zone. The second or middle zone, from 300 to $600 \mathrm{~m}$., includes the Limbombos and a large part of the northern territory, and the predominant rocks are gneiss and the more recent crystalline rocks, such as porphyry, porphyrites, and melaphyres. The third or high zone includes the eastern slopes of the bigh plateau and adjacent areas, with elevations between 600 and $2400 \mathrm{~m}$. The rocks of this zone are principally schists, with a great variety of ancient crystallines, such as granites, granulites, diorites, diabases, gabbros, ete.

The gneiss areas are first seen in the latitude of the Mossurize River, and from here they continue northwards without interruption, forming nearly the whole of the hydrographic basin of the Busi River, except in one or two restricted localities where they are covered by Palæozoic sedimentary strata, which are traversed by granites and other eruptive rocks.

The more ancient sedimentary rocks of the country resemble those of other adjacent parts of South Africa in the absence of fossils; and as a consequence considerable doubt exists regarding their geological age. The author refers to the Silurian or Devonian a thick series of argillaceous and siliceous schists and quartzites, which are developed more particularly along the eastern declivity of the bigh plateau between the Save and the Zambesi, and in the Chimanimani Mountains exhibit a proximate thickness of $1000 \mathrm{~m}$. They have been much disturbed and compressed, and in places they are traversed by diabases and granulites. No fossils have as yet been found in them, and their age is conjectured from their occurrence anterior to rocks considered to be Carboniferous. 
Shales, sandstones, and grits, with beds of coal of Carboniferous age, occur along the left bank of the Zambesi, in the Tete basin, and in the area between it and the Rovugo river. The flora of these beds has been studied by Zeiller: it includes species of Pecopteris, Allipteridium, Alethopteris, Annularia, Sphenophyllum, Cordaites, and Calamodendron, which are considered to indicate the horizon of the Upper Carboniferous in Europe. Some of the bands of coal are of considerable thickness, but the quality is inferior, and owing to their distance from the coast they cannot be worked economically.

To the Karoo Formation the author attributes the conglomerates of Lorenzo Marques which extend along the east face of the Limbombos range nearly to the frontiers of the Transvaal. They consist mainly of stones and boulders of quartzite, and in places also rolled pebbles of amethyst, opal, etc., probably derived from beds of amygdaloidal porphyry. No fossils are known from these conglomerates, and all that can be positively said about them is that they are later than the Carboniferous and Pre-Jurassic, and contemporaneous with the eruptive period which continued from the Carboniferous to the Triassic.

The rocks which are found next above the Karoo series are limestones containing Nummulites, which occur near the base of the slopes of the Chimanimani Mountains, having a very slight easterly dip. They are hard, compact, white or yellow rocks, mainly composed of remains of Nummulites and other Foraminifera, with some moulds of Gasteropods. The Nummulites are small and flattened; two species, N. Biarritzensis and $N$. Beaumonti, can be recognized. These prove the Eocene age of the beds.

Of probably Miocene age are beds of marl overlain by compact white limestones, which occur near Goruja and the junction of the rivers Revue and Busi. The marls contain Trochus patulus (a Miocene species), Ostraa crassissima, and fragmentary shells of Turritella and Cardita.

It is not certain that Pliocene beds are represented south of the Zambesi, but the siliceous sands, which cover so large a portion of the districts of Lorenzo Marques and Inhambane, may be of this period. In some places they reach a thickness of $50 \mathrm{~m}$. In some calcareous beds, which pass up into the sands, there have been found impressions of Tapes, Cerithium, and Tellina with a very characteristic Pliocene aspect, which supports the view that the sands may be Pliocene.

Of comparatively recent deposits may be noticed extensive areas of alluvium near the mouths of the large rivers, and the sand-dunes along the coast. The auriferous sands in the river beds within the Portuguese territory, which have been worked in many places, are too poor to yield a profit, and no other metalliferous deposits of any importance are known.

In the concluding chapter the author gives detailed descriptions of microscopic sections of the crystalline rocks from various localities.

G. J. H. 